\title{
Orman ürünleri sanayinin sertifikasyona yönelik görüşleri: Batı Akdeniz Bölgesi örneği
}

Attitudes and beliefs towards certification of forest products industry: The case of Western Mediterranean Region of Turkey

\author{
Ersin YILMAZ1 \\ Süleyman ALKAN ${ }^{1}$ (D) \\ Arif $\mathrm{KAYACAN}^{1}$ (D) \\ Yunus BAYİR ${ }^{1}$ \\ Zafer MAVI ${ }^{1}$
}

\section{'Batı Akdeniz Ormancılık Araștırma Enstitüsü Müdürlüğü, Antalya}

Sorumlu yazar (Corresponding author) Ersin YILMAZ

eyilmaz33@gmail.com

Geliş tarihi (Received)

10.09.2020

Kabul Tarihi (Accepted)

20.10.2020

Sorumlu editör (Corresponding editor) Nur DİKTAŞ BULUT

nurdiktasbulut@ogm.gov.tr

Atıf (To cite this article): Y1lmaz, E, Alkan, S Kayacan, A , Bayir, Y , Mavi, Z . (2021). Orman ürünleri sanayinin sertifikasyona yönelik görüşleri: Batı Akdeniz Bölgesi örneği . Ormancılık Araștırma Dergisi , 8 (1) , 54-68 . DOI: 10.17568/ ogmoad.792986

\begin{abstract}
$\ddot{0} z$
Araştırmada Batı Akdeniz Bölgesindeki orman ürünleri sanayisine yönelik bir anket çalışması yürütülmüştür. Çalışmanın amaçları; sertifikalı ve sertifikasız imalatçıların arasındaki sertifikasyona yönelik görüşlerdeki farklılıkları belirlemektir. Bu amacın seçilme nedeni, sertifikasyonun gelişen bir olgu olması ve bazı yönlerden bilgi boşluğunun bulunmasıdır. Anket, sertifikasyon konusunda demografik ve görüşe dayalı bilgi toplamak amacıyla kullanılmıştır. Sertifikasız imalatçılar, sertifikalı imalatçılardan daha küçük ölçeklidir. İstatistiklerin tamamı, daha büyük ölçekli orman ürünleri imalatç1larının sertifikalı olmasının beklenebileceğini göstermektedir. Sertifikasyon ve çevresel konular kitle iletişim araçlarında daha fazla yer aldıkça ve toplumda bu konulara güçlü bir ilgi oluştukça, sertifikasız imalatçılar arasında sertifikasyon farkındalığında artış beklenebilir. Sertifikalı ve sertifikasız orman ürünleri imalatçıları sertifikasyon konusunda farklı görüşlere sahiptir. Bu farklı görüşler her bir grubun yaptığı seçimleri etkilemektedir.
\end{abstract}

Anahtar Kelimeler: Sertifikasyon, orman ürünleri endüstrisi, Batı Akdeniz Bölgesi

\begin{abstract}
A survey of manufacturers in Western Mediterranean Region was conducted. The objective of this study was to determine the differences in attitudes and beliefs towards certification between certified and non-certified manufacturers. Because environmental (or green) certification is a developing phenomenon, this objective was chosen and certification has some aspects that remain unknown. The questionnaire was used to collect demographic and attitudinal information from manufacturers about certification. On average, the non-certified manufacturers were smaller than the certified manufacturers. All of the statistics imply that greater forest products manufacturers are more likely to become certified. As certification and environmental issues continue to garner coverage in the media and generate strong interest among the public, it can be expected the increasing awareness of certification among non-certified manufacturers. Certified and non-certified forest products manufacturers hold widely differing views on certification. Those differing beliefs affect to the choices each group makes.
\end{abstract}

Key Words: Certification, forest products industry, Western Mediterranean Region 


\section{Giriş}

Dünya ormanlarının durumuna yönelik toplumun ilgisi ve dünyadaki odun hammaddesi talebi sonucunda ormanlar üzerindeki baskılar 1980'lerden bu yana artmış durumdadır. Bu konular çevresel ilgi gruplarının yönlendirmesiyle 1992 yılındaki Rio Dünya Zirvesinde ön plana çıkmış ve bu zirveye katılan ülkeler, dünya ormanlarını sürdürülebilir şekilde geliştirmek ve izlemek konusunda görüş birliğine varmışlardır. Orman sertifikasyonu, ormansızlaşma ve orman bozulmasının sonuçlarına bir tepki olarak çevresel gruplar tarafından öne sürülmüştür (Rametsteiner ve Simula, 2003).

Sertifikasyon hareketi hala gelişme aşamasındadır ve birçok imalatçı bunun uzun dönemde sağlayacağ1 faydalar konusunda kuşkulara sahiptir. Sertifika veren kuruluşlar bu hareketi özendirmeye çalışsalar da büyük oranda yanlış bilgilenme ve yanlış anlamalardan dolayı bu hareketi yaygınlaştırmak güçtür.

Sertifikasyon konusunda yurtiçi ve yurt dışında yapılan çalışmalar Yılmaz ve ark. (2020a ve b) tarafından incelenmiştir. Buna göre konuyla ilgili yurt dışında yürütülen çalışmalar kapsamında Jayasinghe ve ark., 2007; Ratnasingam ve ark., 2008; Stevens ve ark., 1998; Vlosky ve Ozanne, 1998; Aguilar ve Vlosky, 2007; Bigsby ve Ozanne, 2002; Forsyth ve ark., 1999; Kozak ve ark., 2004; Mohamed ve Ibrahim, 2007; Ozanne ve Vlosky, 1997 ve 2003; Ebeling ve Yasue, 2009; Tikina ve Innes, 2008; Chen ve ark., 2010; Jensen ve ark., 2003; Ozanne ve Vlosky, 2003; Anderson ve Hansen, 2004; Hansen, 1997; Stevens ve ark., 1998; Hubbard ve Bowe, 2005; Vidal ve ark. 2005 sayllabilir. Buna karşın çalışmayla doğrudan veya dolaylı olarak ilgili, Türkiye'de yapılan çalışmalar ise; Geray, 1999; Türkoğlu, 2009; Şener, 2009; Şener, 2016; Şener ve ark., 2011; Karagöz, 2010; Türkoğlu, 2011; Karagöz ve ark., 2011; Türkoğlu ve Tolunay, 2013; Genç, 2014; Şensöz, 2014; Türkoğlu ve Tolunay, 2014; Komut, 2016; Dursun ve Daşdemir, 2016; Koçak, 2016; Koçak ve ark., 2017; Koç, 2016; Dursun ve Daşdemir, 2017; Akyol ve Yıldız, 2018 şeklinde sıralamak mümkündür.

Batı Akdeniz Bölgesinde her ne kadar sertifikalı orman ürünlerine yönelik sınırlı bir talep olsa da bazı firmalar gönüllü olarak sertifikasyonlu olmayı tercih etmektedir. Bu doğrultuda herhangi bir gelişmekte olan olguda olduğu gibi, firmaların sertifikasyona yönelik sahip oldukları temel inanç ve düşüncelerini ortaya koymak faydalı olacaktır.

Bu çalışmada, sertifikasyonun Batı Akdeniz Bölgesi orman ürünleri sanayisindeki etkileri araşt1- rılmıştır. Bu kapsamda birkaç sebeple bu çalışmada öbek olarak sertifikalı ve sertifikasız orta ve büyük ölçekli orman ürünleri firmaları seçilmiştir. Bunlar; Batı Akdeniz Bölgesindeki bu sanayinin üstesinden gelinebilir boyutu, gelecekte sertifikasyonun bu sanayide büyük bir etkiye sahip olma potansiyeli ve yine gelecekte sertifikasyona yönelik olası tercihlerdir. Bu araştırmada Batı Akdeniz Bölgesi için ortaya çıkarılacak sonuçlar ve önemli eğilimler, ülke orman ürünleri sanayi için de uygulanabilir niteliktedir.

$\mathrm{Bu}$ araştırmanın iki ana amacı bulunmaktadır. Bunlar; Batı Akdeniz Bölgesindeki sertifikalı ve sertifikasız orman ürünleri imalatçılarının genel özelliklerini tanımlamak ve bu imalatçıların sertifikasyon uygulamasına yönelik görüşlerini karşılaştırmaktır.

\section{Materyal ve Yöntem}

\subsection{Materyal}

Araştırmadaki veri toplama ana verinin sağlanmasıyla ilgili olmuştur. Batı Akdeniz Bölgesindeki sertifikasız orman ürünleri imalatçılarına yönelik ana veriler 2018 yılında bir "anket formu" yoluyla toplanmıştır. Toplanan veriler iki ayrı grup oluşturmuştur. İlk veri grubu, sertifikasız orman ürünleri imalatçılarının odun hammaddesi sertifikasyonuna yönelik görüşlerinin ve algılarının ortaya konmasını sağlamıştır.

Anketler, her bir firma sahibi veya üst yöneticisi tarafından yüz yüze görüşme yoluyla doldurulmuştur. Bu kapsamda ele alınan konulara; 1) Odun hammaddesi sertifikasyon uygulamasına yönelik farkındalık ve bilgi, 2) Odun hammaddesi sertifikasyon uygulamasına yönelik algılar, 3) Firmanın sertifikalı bir ürüne dönüşüm yapması konusunda dış ortamdan herhangi bir baskı hissetmesi ve 4) Odun hammaddesi sertifikasyon akımının önemi ve uzun dönemdeki faydalılığ 1 konusundaki görüşler dâhildir. Bunun yanında Batı Akdeniz Bölgesindeki sertifikalı orman ürünleri imalatçıları ile ilgili veriler de toplanmıştır.

$\mathrm{Bu}$ doğrultuda anketi cevaplayanlardan 5'li Likert ölçeği üzerinde birkaç ifadeyi kabul edip etmedikleri yönünde puanlamaları istenmiştir. Toplanan bu veri orman ürünleri sanayinin yapısına 1 şık tutmuştur. Bu kapsamda anketi cevaplayanlardan firmalarının ürettiği ürün çeşitleri, yıllık üretilen orman ürünleri miktarı ve bunların yıllık satış rakamları konularında bilgiler vermeleri istenmiştir. Bu bölümdeki araştırma amaçlarına ve toplanacak ana verilere dayalı olarak araştırmayı gerçekleştirmek üzere bir "anket formu” geliştirilmiştir. Bu 
anket formunun hazırlanmasında Alt (2001), Vidal ve ark. (2005), Owari ve ark. (2006) ve Bond ve ark. (2014) tarafindan yapılan yayınlardan faydalanılmıştır.

\subsection{Yöntem}

\subsubsection{Hipotezler}

Araştırmanın amaçları doğrultusunda, farklı istatistik teknikler yardımıyla sınanan hipotezler şunlardir:

$\mathrm{H}_{1}$ : İki öbeğin (sertifikalı ve sertifikasız orman ürünleri imalatçılarının) her birisinin düzenleyici ve denetleyici kuruluşlara yönelik güven sıralamasinda farklılık mevcuttur.

$\mathrm{H}_{2}$ : İki öbek tarafından düzenleyici ve denetleyici kuruluşlara yönelik güven sıralamasında farklılık mevcuttur.

$\mathrm{H}_{3}$ : İki öbeğin her birisinin sertifikasyon uygulamasına yönelik görüşlerinde farklılık mevcuttur.

$\mathrm{H}_{4}$ : İki öbek arasında sertifikasyon uygulamasına yönelik görüşlerde farklılık mevcuttur.

$\mathrm{H}_{5}$ : İki öbeğin her birisinin sertifikasyondan elde edilebilecek faydalara yönelik görüşlerinde farkl1lik mevcuttur.

$\mathrm{H}_{6}$ : İki öbek arasında sertifikasyondan elde edilebilecek faydalara yönelik görüşlerde farklılık mevcuttur.

$\mathrm{H}_{7}$ : İki öbeğin her birisinin sertifikasyona katılımı etkilediğine inanılan engellere/sorunlara yönelik görüşlerinde farklılık mevcuttur.

$\mathrm{H}_{8}$ : İki öbek arasında sertifikasyona katılımı etkilediğine inanılan engellere/sorunlara yönelik görüşlerde farklılık mevcuttur.

$\mathrm{H}_{9}$ : Sertifikasız imalatçıların sertifikasyona üye olma istekliliğine yönelik koşulları arasında farklilık mevcuttur.

$\mathrm{H}_{10}$ : Sertifikasyona ihtiyaç duyan sertifikasız imalatçıların her birisinin ihtiyaç nedenleri arasında farklilık mevcuttur.

\subsubsection{Hedef kitle}

Araştırmada iki hedef kitle bulunmaktadır. Bunlar; Batı Akdeniz Bölgesindeki sertifikasız orman ürünleri imalatçıları ve sertifikalı orman ürünleri imalatçılarıdır. Sosyal Güvenlik Kurumu kayıtlarına göre çalışan sayısı 30 kişiden fazla orta ve büyük ölçekli 10 sertifikasız orman ürünleri imalatçıları çalışmaya dâhil edilmiştir. Sertifikalı or- man ürünleri imalatçıları olarak ise araştırmanın yürütüleceği zamanda bağımsız bir üçüncü taraf sertifikasyon kuruluşu olan FSC tarafından sertifikasyona tabi tutulmuş orman ürünleri üreten 4 imalatçı alınmıştır. Çalışmanın FSC sertifikalı firmalarla sınırlandırılmasının nedeni, FSC'nin halen dünyada ve bilhassa ülkemizde önemli ilerleme gösteren sertifikasyon kuruluşu olmasıdır.

\subsubsection{Veri çözümlemeleri ve değerlendirme yöntemleri}

Batı Akdeniz Bölgesi orman ürünleri sanayi hakkında tanımlayıcı bilgi elde etmeye yönelik olarak aşağıdaki konularda bilgi toplanmıştır:

- Çalışan sayısı,

- Üretim miktarı,

- Yıllık satış rakamları,

- Yılda çalışılan gün sayısı,

- Günde çalışılan saat sayısı,

- Sertifikasız orman ürünleri üretim miktarı,

- Sertifikalı orman ürünleri üretim miktarı.

Sertifikalı ve sertifikasız orman ürünü imalatçılarının sertifikasyona yönelik görüşleri belirlenirken veri analizi aşamasında, her bir öbeğe yönelik sıralamada istatistiksel açıdan önemli farklılıklar olup olmadığını belirlemede "tek yönlü varyans analizi (ANOVA)" kullanılmıştır. Her iki öbeğin sıralamasinda 0,05 düzeyinde istatistiksel olarak önemli farklılıkları tespit etmek ve farklı kuruluşları gruplandırmak için iki öbeğin sonuçları üzerine "Tukey testi" uygulanmıștır. Ardından iki öbek tarafından görüşlerde herhangi bir istatistiksel farklılık olup olmadığını belirlemek için " $t$-testi" karşılaştırmaları gerçekleştirilmiştir.

\subsubsection{Güvenilirlikler}

Araştırmada kullanılan ölçeklerin genel güvenilirlik düzeylerini belirlemek için Cronbach Alpha katsayısı hesaplanmıştır. Sonuçlar \%95 güven aralığında, anlamlılık p $<0,050$ düzeyinde çift yönlü olarak değerlendirilmiştir (Tablo 1).

Cronbach Alpha katsayısının değerlendirilmesinde kullanılan değerlendirme kriteri (Özdamar, 2009);

$0,000 \leq \alpha<0,400$ ise ölçek güvenilir değildir,

$0,400 \leq \alpha<0,600$ ise ölçek düşük güvenilirliktedir, $0,600 \leq \alpha<0,800$ ise ölçek oldukça güvenilirdir,

$0,800 \leq \alpha<1,000$ ise ölçek yüksek derecede güvenilirdir.

$\mathrm{Bu}$ çalışmadaki ölçeklerin güvenilirlik düzeyleri 
0,750 (\%75,0) ile 0,937 (\%93,7) arasında değişmektedir. $\mathrm{Bu}$ nedenle ölçeklere ait ifadelerin oldukça veya yüksek düzeyde güvenilir oldukları Tablo l'de görülmektedir.

Tablo 1: Ölçeklere ilişkin güvenilirlik düzeyleri Table 1: Reliability levels for the scales

\begin{tabular}{lcc}
\hline Ölçek & $\begin{array}{c}\text { Cronbach } \\
\text { alpha }\end{array}$ & $\begin{array}{c}\text { Soru } \\
\text { sayıs1 }\end{array}$ \\
\hline $\begin{array}{l}\text { Sertifikasız imalatçıların sertifi- } \\
\text { kasyona (çevresel idareye) ihtyaç } \\
\text { duyma durumları }\end{array}$ & 0,750 & 7 \\
$\begin{array}{l}\text { İmalatçıların sertifikasyona } \\
\text { yönelik görüşleri } \\
\text { İmalatçıların sertifikasyondan } \\
\text { hangi faydaların elde } \\
\text { edilebileceğine yönelik görüşleri }\end{array}$ & 0,839 & 12 \\
$\begin{array}{l}\text { İmalatçıların sertifikasyona } \\
\text { üye olma istekliliğine yönelik } \\
\text { koşullar }\end{array}$ & 0,919 & 23 \\
$\begin{array}{l}\text { İmalatçıların sertifikasyon } \\
\text { önündeki engellere/sorunlara } \\
\text { yönelik görüşleri }\end{array}$ & 0,799 & 9 \\
\hline
\end{tabular}

\section{Bulgular}

Batı Akdeniz Bölgesindeki orman ürünleri sanayi çoğunlukla küçük firmalardan oluşsa da birkaç büyük firma da bulunmaktadır. Bu yap1, bölgedeki sanayinin özelliklerinin sağlıklı bir şekilde ortaya konmasını güçleştirmektedir. Sanayinin doğru bir profili, hem sanayi içindeki hem de dışındaki plancılara yardımcı olacaktır. Aynı zamanda sanayideki firma boyutlarının ve sanayinin yapısının net bir şekilde belirlenmesi, bu imalatçılara hammadde sağlayanlar ve bu sanayi konusunda çalışma yapanlar için önem taşımaktadır.

Sertifikasyonun orman ürünlerine yayılması ülkemizde ve bölgede yavaş seyretmektedir. Batı Akdeniz Bölgesinde sertifikasyona tabi olmayı seçen birkaç imalatçı bulunmaktadır. Bu sertifikalı imalatçıların varlığı, sertifikalı ve sertifikasız imalatçıların görüşlerindeki ve yapılarındaki farklılığ inceleme firsatı vermektedir. Sertifikalı ve sertifikasız imalatçıların görüşlerindeki farklılıkların ortaya konulması, niçin bazılarının sertifikalı olmayı seçerken, niçin bazılarının sertifikalı olmamayı tercih ettikleri konusuna 1 şık tutabilecektir. Sertifikasyon gibi gelişmekte olan bir akımda böylesi bilgiler, olgunun anlaşılmasına yardımcı olma yönünde de önemli katkılar sağlamaktadır.

Batı Akdeniz Bölgesinde yıllık olarak üretilen sertifikalı orman ürünleri miktarı konusunda herhangi bir tahmin bulunmamaktadır. Sertifikalı ima- latçıların yapılarının ortaya konulması, ne kadar sertifikalı orman ürünü üretildiğini gösterecek ve sertifikalı imalatçıların sertifikasız imalatçılarla karşılaştırıldığında hangi farklılıklara sahip olduklarını gösterecektir. Batı Akdeniz Bölgesinde üretilen sertifikalı orman ürünleri miktarının doğru bir tahmininin yapılması ve sertifikalı orman ürünleri imalatçılarının özelliklerinin belirlenmesi, sertifikasyon olgusu konusunda çalışma yapanlara yardımcı olacak ve sertifikalı orman ürünlerine ait büyümenin izlenmesinde bir değerlendirme sağlayacaktır.

\subsection{Batı Akdeniz Bölgesi Orman Ürünleri Sanayi}

Anket formunu cevaplayanlardan ilk olarak orman ürünleri sanayi hakkında tanımlayıcı bilgi elde etmeye yönelik tasarlanmış genel sorulara cevap vermeleri istenmiştir. Bu bilgilere; genel üretim bilgileri, firmaların büyüklüğü ve orman ürünlerinin yıllık satış rakamları dâhil olmuştur. Bu soruları hem sertifikalı hem de sertifikasız imalatçıların cevaplamaları istenmiştir.

\subsection{1. Çalışan sayısı}

Anketi cevaplayanlardan 2017 yılında istihdam ettikleri yarı-zamanlı ve tam-zamanlı çalışanların sayısını belirtmeleri istenmiştir (Tablo 2 ve Tablo 3). Bu bilgi, Batı Akdeniz Bölgesi orman ürünleri sanayisini oluşturan firmaların boyutunu tahmin etmede faydalı olmuştur.

Tablo 2: Çalışan tipi itibariyle sertifikalı olmayan imalatçı firmaların 2017 yılında istihdam ettikleri çalışanların sayısı

Table 2: Number of employees employed in 2017 by non-certified companies by type of employee

\begin{tabular}{lcccc}
\hline Çalışan tipi & Ortalama & Medyan & Maks. & Min. \\
\hline Yarı-zamanlı & 13,20 & 1 & 80 & 1 \\
Tam-zamanlı & 99,30 & 66 & 290 & 12 \\
\hline
\end{tabular}

Tablo 3: Çalışan tipi itibariyle sertifikalı imalatçı firmaların 2017 yılında istihdam ettikleri çalışanların sayısı

Table 3: Number of employees employed in 2017 by certified companies by type of employee

\begin{tabular}{ccccc}
\hline Çalışan tipi & Ortalama & Medyan & Maks. & Min. \\
\hline Yarı-zamanlı & 1 & 1 & 1 & 1 \\
Tam-zamanlı & 373,50 & 232 & 1000 & 30 \\
\hline
\end{tabular}

Sertifikasız imalatçılar, sertifikalı imalatçılardan daha fazla yarı-zamanlı çalışan kullanmaktadır. Nitekim sertifikasız imalatçılar çalışmalarında ortalama 13,20 yarı-zamanlı çalışan, sertifikalı ima- 
latçılar ortalama 1 yarı-zamanlı çalışan istihdam etmiştir. Bununla birlikte iki grubun yarı-zamanlı istihdama yönelik medyan düzeyleri aynı olup, 1 yarı-zamanlı çalışanlık 1 medyan düzeyi kullanmaktadir.

İmalatçıların istihdam ettikleri tam-zamanlı çal1şan sayılarına bakıldığında, bu iki öbek arasında önemli bir fark bulunmaktadır. Nitekim sertifikasız imalatçılarla karşılaştırıldığında sertifikalı imalatçılar yaklaşık 4 kat fazla sayıda tam-zamanlı çalışan kullanmaktadır. Sertifikasız imalatçılar ortalama 99,30 tam-zamanlı çalışan istihdam ederken, sertifikalı imalatçılar 373,50 tam-zamanlı çalişan istihdam etmektedir.

\subsection{2. Üretim miktarı}

Sertifikalı ve sertifikasız imalatçıların yıllık üretim düzeyleri incelendiğinde (Tablo 4), bu iki öbekteki firmaların boyutları arasındaki farklılıkların daha belirgin olduğu görülmüştür. Bu nedenle anketi cevaplayanlardan, firmalarının yıllık orman ürünleri üretimini belirtmeleri talep edilmiştir.

Tablo 4: Firma tipleri itibariyle 2017 y1lı orman ürünleri üretimi $\left(\mathrm{m}^{3}\right)$

Table 4: 2017 forest product production $\left(\mathrm{m}^{3}\right)$ by type of companies

\begin{tabular}{lcccc}
\hline Çalışan tipi & Ortalama & Medyan & Maks. & Min. \\
\hline Sertifikasız & 7.413 & 8.000 & 13.000 & 95 \\
Sertifikalı & 242.541 & 235.000 & 500.000 & 165 \\
\hline
\end{tabular}

Sertifikalı firmaların sertifikasız firmalara göre yaklaşık 30 kat fazla orman ürünleri ürettiği ortaya çıkmıştır. Sertifikasız firmalar yılda ortalama yaklaşı $7.413 \mathrm{~m}^{3}$ orman ürünleri üretirken, sertifikalı firmalar yılda ortalama $242.541 \mathrm{~m}^{3}$ orman ürünleri üretmiştir. Aynı zamanda sertifikasız imalatçılar yılda maksimum $13.000 \mathrm{~m}^{3}$ orman ürünleri üretirken, sertifikalı imalatçılar yılda maksimum $500.000 \mathrm{~m}^{3}$ orman ürünleri üretmiştir. İki öbeğe yönelik medyan üretim düzeyleri incelendiğinde, sertifikasız imalatçılar için medyan üretim düzeyi $95 \mathrm{~m}^{3}$ iken sertifikalı üreticiler için $165 \mathrm{~m}^{3}$ ’tür.

\subsubsection{Yıllık satış rakamları}

Bu çalışmadaki farklı firmalara yönelik yıllık satış rakamları, farklı öbeklerdeki firmaların boyutunun karşılaştırılmasında bir diğer araç olmuştur. Bunun için anketi cevaplayanlardan yıllık satışlarını belirli bir seçim listesindeki uygun aralığı seçerek belirtmeleri istenmiştir. Böylece çalışmadaki her bir satış rakamı kategorisine düşen firma sayısı ortaya konulmuştur.
Sertifikasız firmaların çoğunun satışları 1 milyon TL ile 4,9 milyon TL aralığında iken, sertifikalı imalatçıların 100 milyon TL'den fazla yıllık satış rakamına sahip olduğu ortaya çıkmıştır.

\subsubsection{Yılda çalışılan gün sayısı}

Katılımcılardan, tesislerinin yılda çalıştı̆̆ı gün sayılarını belirtmeleri istenmiştir. Sertifikasız imalatçıların \%80'i yılda 276-325 gün arasında çalışmakta iken sertifikalı imalatçıların \%75'i yılda 301 günden fazla çalışmaktadır.

\subsubsection{Günde çalışılan saat sayısı}

Anketi cevaplayanlardan, tesislerinin günde çalıştığı ortalama saat sayısını belirtmeleri de istenmiştir. Sertifikasız imalatçıların çoğunluğu günde 8 saatlik bir vardiya halinde çalışmakta iken iki tesisin tek vardiyadan kısa (7,5 saat) ve yine iki tesisin tek vardiyadan uzun (9 saat) çalıştığ tir. Sertifikalı imalatçılardan 1 firma günde sadece bir vardiya çalıştığını belirtmiş olsa da 9 saat, 21 saat ve 24 saat çalıştığını bildiren birer adet sertifikalı firma da mevcuttur.

\subsubsection{Sertifikasız orman ürünleri üretimi}

Sertifikalı ve sertifikasız orman ürünleri imalatçılarından kullandıkları ağaç türü ve ürün çeşitleri itibariyle toplam orman ürünleri üretimlerinin dağılımını belirtmeleri istenmiştir (Tablo 5). Sertifikalı imalatçıların sertifikasız orman ürünleri üretimini sürdürmeleri söz konusu olup, toplam çıktılarının sadece belirli bir yüzdesini sertifikalı orman ürünü olarak üretmektedirler. $\mathrm{Bu}$ nedenle bu imalatçılar, sertifikasız orman ürünleri toplamına dâhil edilmiştir.

Tablo 5: Türler itibariyle 2017 yılı sertifikalı olmayan orman ürünleri üretimi

Table 5: 2017 non-certified forest product production by species

\begin{tabular}{lc}
\hline \multicolumn{1}{c}{ Türler } & $\begin{array}{c}2017 \text { yılı üretim yüzdesi } \\
(\%)\end{array}$ \\
\hline Kızılçam & 48,7 \\
Karaçam & 16,4 \\
Ladin & 13,7 \\
Sarıçam & 9,1 \\
Kayın & 7,6 \\
Meşe & 2,5 \\
Dişbudak & 1,0 \\
Yalancı ceviz (Karya) & 0,5 \\
Sedir & 0,3 \\
Akçaağaç & 0,0 \\
Huş & 0,0 \\
Diğer & 0,0 \\
\hline
\end{tabular}


2017 yılı sertifikasız orman ürünleri için en çok kullanılan tür, toplam üretimin \%48,7'sine sahip kızılçamdır. Sertifikasız orman ürünleri için ikinci en çok kullanılan tür, toplam üretimin $\% 16,4$ 'üne sahip karaçamdır. 2017 yılı üretiminin \%13,7'sine sahip ladin, \%9,1'ine sahip sarıçam, \%7,6'sına sahip kayın, \%2,5'ine sahip meşe, \%1,0'ına sahip dişbudak, \%0,5'ine sahip yalancı ceviz (karya) ve $\% 0,3$ 'üne sahip sedir yıllık üretimin geri kalanını oluşturmaktadır.

Anketi cevaplayanlardan aynı zamanda üretilen orman ürünleri tipleri itibariyle 2017 y1lı toplam sertifikasız üretimlerinin dağılımını belirtmeleri de istenmiştir (Tablo 6).

Tablo 6. Ürün tipleri itibariyle 2017 y1lı sertifikalı olmayan orman ürünleri üretimi

Table 6. 2017 non-certified forest product production by proct type

\begin{tabular}{lc}
\hline Ürün tipi & $\begin{array}{c}2017 \text { y1lı üretim yüzdesi } \\
(\%)\end{array}$ \\
\hline Kereste & 48,4 \\
MDF lam & 9,8 \\
Kisa tomruk & 7,8 \\
Yonga levha & 7,8 \\
Mobilya & 6,3 \\
Masif panel & 5,1 \\
Kapı sereni & 3,1 \\
Lif levha & 3,1 \\
Odun parke & 2,3 \\
Kaplama & 2,0 \\
Laminant & 2,0 \\
Lamine kiriş & 1,6 \\
Kontrplak & 0,4 \\
Kağit & 0,0 \\
Karton & 0,0 \\
Diğer & 0,4 \\
\hline
\end{tabular}

Üretilen orman ürünü tipleri arasında önde gelen, yıllık sertifikasız toplam orman ürünü üretiminin $\% 48,4$ 'üne sahip kereste orman ürünüdür. Bunu izleyen diğer orman ürünü tipleri ise sirasıyla toplam yıllık sertifikasız orman ürünü üretiminin \%9,8'ine sahip MDF lam, \%7,8'ine sahip k1sa tomruk, \%7,8'ine sahip yonga levha, \%6,3'üne sahip mobilya, \%5,1'ine sahip masif panel, \%3,1'ine sahip kapı sereni, \%3,1'ine sahip lif levha, \%2,3'üne sahip odun parke, \%2,0'1na sahip kaplama, \%2,0'1na sahip laminant, \%1,6'sina sahip lamine kiriş, \%0,4'üne sahip kontrplak ve \%0,4'üne sahip diğer orman ürünleridir.

\subsubsection{Sertifikalı orman ürünleri üretimi}

Sertifikalı orman ürünleri imalatçılarının imal ettikleri sertifikalı materyal miktarı konusunda bilgi vermeleri istenmiş ve imal ettikleri sertifikalı orman ürünleri konusunda bilgilendirme yapmaları talep edilmiştir.

Bunun için ilk olarak anketi cevaplayan sertifikalı imalatçılardan, sertifikalı orman ürünleri olarak ürettikleri her bir türdeki orman ürünü yüzdesi konusunda bilgi vermeleri istenmiştir (Tablo 7).

Tablo 7. Türler itibariyle 2017 y1lı sertifikalı orman ürünleri üretimi

Table 7. 2017 certified forest product production by species

\begin{tabular}{lc}
\hline Türler & $\begin{array}{c}2017 \text { y1lı üretim yüzdesi } \\
(\%)\end{array}$ \\
\hline Kayın & 36,7 \\
Ladin & 33,3 \\
Kızılçam & 30,0 \\
Karaçam & 0,0 \\
Sedir & 0,0 \\
Meşe & 0,0 \\
Akçaağaç & 0,0 \\
Huş & 0,0 \\
Yalancı ceviz (Karya) & 0,0 \\
Diğer & 0,0 \\
\hline
\end{tabular}

Buna göre 2017 yılı sertifikalı orman ürünleri için en çok kullanılan tür, toplam üretimin \%36,7'sine sahip kayındır. Sertifikalı orman ürünleri için ikinci en çok kullanılan tür toplam üretimin \%33,3'üne sahip ladin iken, üçüncü en çok kullanılan tür toplam üretimin \%30,0’una sahip kızılçamdır.

Ardından sertifikalı imalatçılardan, farklı orman ürünleri itibariyle sertifikalı materyallerinin dağılımını belirtmeleri istenmiştir (Tablo 8). Bu bilgi, sertifikasız orman ürünlerine yönelik aynı sorunun cevabıyla karşılaştırılmıştır. Böylece bu iki ürün arasında herhangi bir fark olup olmadığ 1 belirlenmiştir.

Tablo 8. Ürün tipleri itibariyle 2017 y1lı sertifikalı orman ürünleri üretimi

Table 8. 2017 certified forest product production by proct type

\begin{tabular}{lc}
\hline Ürün tipi & $\begin{array}{c}2017 \text { y1lı üretim yüzdesi } \\
(\%)\end{array}$ \\
\hline Kisa tomruk & 33,3 \\
Lamine & 33,3 \\
Panel & 33,3 \\
Lamba ve zivana tahta & 0,0 \\
Kereste & 0,0 \\
Odun parke & 0,0 \\
Ahşap panjur & 0,0 \\
Diğer & 0,0 \\
\hline
\end{tabular}


2017 yılında üretilen sertifikalı orman ürünlerinde kullanılan ürün tipleri, \%33,3'er üretim yüzdesi ile kısa tomruk, lamine ve panel olmuştur.

Sertifikalı orman ürünü üretimi ile sertifikasız orman ürünü üretimine yönelik sonuçlar karşılaşt1rıldığında önemli farklılıklar ortaya çıkmaktadır. Kisa tomruk \%33,3 olarak üretilen sertifikalı orman ürünlerinin yüzdesi, k1sa tomruk \%7,8 olarak üretilen sertifikasız orman ürünlerinin yüzdesinden çok daha yüksektir. Sertifikasız üretimin en fazla üretilen tipi olan ve \%48,4'ünü oluşturan kereste üretimi, sertifikalı bir biçimde hiç üretilmemiştir.

\subsection{Sertifikalı ve sertifikasız orman ürünü imalatçılarının sertifikasyona yönelik tercihleri}

Anketi cevaplayanlardan, sertifikasyon konusundaki birkaç ifadeyi kabul edip etmeme düzeyini puanlamaları istenmiştir. Böylece ankete cevap verenlerin firmaları ve üretimleri konusunda tanımlayıcı bilgiler elde edilmiştir. Ayrıca bu bilgiler, bu iki öbek arasında görüş farklılığ1 olup olmadığını inceleme açısından da faydalı olmuştur.

\subsubsection{Düzenleyici ve denetleyici makamlara yönelik tercih}

Anketi cevaplayanlardan beş farklı düzenleyici ve denetleyici kuruluş arasındaki tercihlerini puanlamaları istenmiştir. Anketi cevaplayanlar bu aşamada orman ürünü imalatçılarının sertifikasyon taleplerini düzenleme ve denetleme yeteneğine sahip olma durumlarına göre kuruluşlara puan vermişlerdir. Cevap verenlerin puanlaması istenilen 5 kuruluşa; "Özel bir üçüncü taraf sertifikasyon firması (FSC, PEFC gibi)", "Bir devlet kuruluşu (Türk Patent ve Marka Kurumu gibi)", "Orman ürünleri firmalarının bizzat kendileri”, "Bir STK çevre örgütü" ve "Orman ürünleri sanayi ticari birlikleri veya meslek odaları" dâhil olmuştur. Cevap verenlerden ilgili kuruluşa duydukları güven düzeyine dayalı olarak 1'den 5'e kadar kuruluşları puanlamaları istenmiş ve 1 puan olarak cevap verilen kuruluş en fazla güven duyulan kuruluş olarak kabul edilmiştir.

İlk veri analizi aşamasında, her bir öbeğe yönelik sıralamada istatistiksel açıdan önemli farklılıklar mevcut olup olmadığını belirlemede "Tek yönlü varyans analizi (ANOVA)" kullanılmıştır. Sertifikasız imalatçıların yaptığı sıralamada 0,05 önem düzeyinde önemli farklılıkların olduğu belirlenmiştir. Suralamanın istatistiksel olarak farklı olduğu belirlendikten sonra farklı kuruluşları gruplandırmak için sertifikasız imalatçılara yönelik sonuçlar üzerine “Tukey HSD testi” uygulanmıştır.
Tukey testi araştırmacıya, denemedeki ortalamaların istatistiksel olarak benzer olduğunu belirlemek suretiyle sonuçları gruplandırmaya imkân vermektedir.

Sertifikasız imalatçılar; özel bir üçüncü taraf sertifikasyon firmasını, orman ürünleri sanayi ticari birlikleri veya meslek odalarını, orman ürünleri firmalarının bizzat kendilerini ve bir devlet kuruluşunu çevresel sertifikasyon taleplerini düzenleme ve denetlemede sahip oldukları güven düzeyinde istatistiksel olarak eşdeğer olarak sıralamışlardır. Bu gruplar listenin üst kısmında sıralanmıştır. Buna karşın bir çevre örgütü ölçeğin en altında yer almaktadır.

Sertifikalı imalatçılardan da düzenleyici ve denetleyici makamlara yönelik tercihlerini sıralamaları istenmiştir. Bu öbeğe yönelik gerçekleştirilen tek yönlü varyans analizi sonuçlarına göre, bu öbeğin sıralamasında 0,05 düzeyinde istatistiksel olarak önemli farklılıkların olmadığı ortaya çıkmıştır.

Sertifikalı imalatçıların cevapları, sertifikasız imalatçıların cevaplarına oldukça benzerdir. Sertifikalı imalatçılar da sertifikasız imalatçılarda olduğu gibi ilk üç en güvenilir kuruluşlar olarak özel bir üçüncü taraf sertifikasyon firmasını, orman ürünleri sanayi ticari birliklerini veya meslek odalarını ve orman ürünleri firmalarının bizzat kendilerini sıralamıştır. Nihayet sertifikalı imalatçıların düzenleyici ve denetleyici kuruluşlar alt grubunu sırasıyla bir çevre örgütü ve bir devlet kuruluşu oluşturmaktadır.

Cevap verenlerin bireysel karşılaştırmaları tamamlandiktan sonra iki öbeğin düzenleyici ve denetleyici kuruluş sıralamalarında herhangi bir istatistiksel farklılığı belirlemek üzere t-testi karşılaştırmaları yapılmıştır.

Bu çalışmada iki öbek, beş düzenleyici ve denetleyici kuruluştan iki düzenleyici ve denetleyici kuruluşa, yani bir devlet kuruluşuna ve bir çevre örgütüne istatistiksel olarak farklı sıralama vermiştir. Nitekim sertifikasız imalatçılar bir devlet kuruluşunu beş seçimden dördüncü olarak sıralamışken sertifikalı imalatçılar beş seçimden beşinci olarak sıralamıştır. Benzer şekilde sertifikasız imalatçılar bir çevre örgütünü beş seçimden beşinci olarak sıralamışken sertifikalı imalatçılar beş seçimden dördüncü olarak sıralamıştır.

$\mathrm{Bu}$ iki öbek, geri kalan üç kuruluşa istatistiksel olarak benzer sıralama vermiştir. Her iki öbek de, zirvenin en üstünden aşağı doğru özel bir üçüncü taraf sertifikasyon firmasını, orman ürünleri sanayi ticari birliklerini veya meslek odalarını ve orman 
ürünleri firmalarının bizzat kendilerini sıralamıştır.

\subsubsection{Sertifikasız imalatçıların sertifikasyona (çevresel idareye) ihtiyaç duyma durumları}

Sertifikasız imalatçılara, sertifikasyon ihtiyacında olup olmadıkları sorulmuştur. Bu soru sadece sertifikasız imalatçılara yöneltilmiştir. Ardından sertifikasyon ihtiyacında olan sertifikasız imalatçılara, sertifikasyon ihtiyacının olası nedenleri sorulmuş ve her bir nedeni kabul edip etmeme düzeylerini oylamaları istenmiștir.

Olası bu 7 neden şunlardır; üst yönetimin sorumluluk hissetmesi, Devlet yasaları, kamu baskısı (örneğin malın tutundurulması, boykotu vb.), müşterilerin "yeşil" ürünlere yönelik talepleri, olası maliyet tasarrufları, firma imajını koruma arzusu ve pazarda rekabetçi bir avantaja sahip olma veya bunu koruma arzusu.

$\mathrm{Bu}$ sorunun sonuçları üzerine tek yönlü varyans analizinin uygulanmasından sonra sonuçlar arasında istatistiksel farklılıkların olduğu belirlenmiş, cevapları gruplandırmak için "Tukey HSD testi" kullanılmıştır.

Sertifikasız imalatçılar tarafından sertifikasyon ihtiyacına yönelik nedenlerin üst grubunu; kamu baskıs1, müşterilerin "yeşil" ürünlere yönelik talepleri, olası maliyet tasarrufları ve pazarda rekabetçi bir avantaja sahip olma veya bunu koruma arzusu oluşturmaktadır. Son gruplandırmada ise firma imajını koruma arzusu ve üst yönetimin sorumluluk hissetmesi bulunmakta, sertifikasız imalatçılar bu nedenleri, sertifikasyon taahhüdünde bulunma ihtiyacına yönelik nedenler olarak kabul etmektedirler.

\subsubsection{Sertifikasız imalatçıların sertifikalı hammaddeye yönelik ödeme istekliliği}

Sertifikasız imalatçılara, sertifikalı orman ürünleri imalatında kullanıma yönelik sertifikalı hammadde için sertifikasız hammaddenin piyasa fiyatı üzerinde herhangi bir fazladan fiyat ödeyebilme (ödeme istekliliği) durumu sorulmuştur. Bu kapsamda bu imalatçılara seçim yapmaları için üç olası cevap sunulmuştur. Bu cevaplardan sadece birinin seçilmesi istenmiştir.

Cevap verenlerin \%10'u sertifikalı hammadde satın alacağı zaman sınırsız bir fazladan fiyat ödemeye istekli iken, cevaplayanların \%50'si sertifikalı hammadde satın alacağı zaman herhangi bir fazladan fiyat ödemeye istekli değildir.

Fazladan bir fiyat ödemeye istekli olduğunu belirten cevap verenlerin \%40'1na, ödemeye istekli olduğu maksimum fazladan fiyatı belirtmeleri istenmiştir.

Sertifikasız imalatçıların ödemeye istekli olduğu sertifikalı hammaddeye yönelik ortalama fazladan fiyat, sertifikasız materyalin piyasa fiyatının \%3,25 fazlasıdır. Cevaplar, en düşük sertifikasız materyalin piyasa fiyatının \%1'inden, en yüksek sertifikasız materyalin piyasa fiyatının \%15'ine kadar değişiklik göstermiştir.

\subsubsection{Sertifikasız imalatçıların $\mathrm{CoC}$ sertifikasyonuna yönelik ödeme istekliliği}

Sertifikasız imalatçılardan CoC sertifikasyonuna yönelik ödeme istekliliğini, bir başka ifadeyle, sertifikasız imalatçılara CoC sertifikasyonu için sertifikasız orman ürünlerinin piyasa fiyatı üzerinde herhangi bir fazladan fiyat ödeyebilme durumunu belirtmeleri istenmiştir.

Cevap verenlerin \%80'i eğer ücretsiz olursa firmalarının $\mathrm{CoC}$ sertifikasyonuna tabi olacağını belirtmişken, \%20'si herhangi bir maliyete maruz kalması durumunda firmalarının $\mathrm{CoC}$ sertifikasyonuna tabi olmayacağını ifade etmiştir.

\subsubsection{Sertifikasız imalatçıların sertifikalı orman ürünleri üretimine başlamak için ihtiyaç duyduğu fazladan fiyat}

Sertifikasız imalatçılardan, sertifikalı orman ürünleri üretimine başlamak için bu ürünlere yönelik müşterilerinden (alıcılarından) almaya ihtiyaç duyduğu fazladan fiyatın (sertifikasız orman ürünlerinin müşteriye ödettireceği piyasa fiyatı üzerindeki miktarının) ne olduğu sorulmuştur. İmalatçılara yine olası üç cevap verilmiş ve cevaplardan birini seçmeleri istenmiştir.

Ankete katılan sertifikasız imalatçıların \%70'i, eğer fazladan fiyat yoksa sertifikalı orman ürünleri imal etmeye istekli olacağını belirtmiştir. Buna karşın imalatçıların \%30'u, herhangi bir fazladan fiyat durumunda sertifikalı orman ürünleri imal etmeye isteksiz olacağını dile getirmiştir.

\subsection{6. İmalatçıların sertifikasyona yönelik görüşleri}

Sertifikalı ve sertifikasız imalatçılardan, sertifikasyon akımı konusundaki birkaç ifadeyi kabul edip etmeme yönünde puanlamaları istenmiştir. $\mathrm{Bu}$ soru, imalatçıların sertifikasyon akımı yönündeki görüşlerini ortaya koyacak şekilde tasarlanmıştır. Her bir gruptan elde edilen cevaplar, farkl1lık olup olmadığını görme yönünde "Tek yönlü varyans analizi” kullanılarak çözümlenmiştir. İki öbek için cevaplar arasında istatistiksel açıdan önemli fark- 
l11ıklar olduğu bulunmuştur. Daha sonra cevapları gruplandırmak için cevaplar, "Tukey HSD" testi kullanılarak analiz edilmiştir. Sonrasında iki öbek arasında her bir ifadeye yönelik cevaplarda istatistiksel farklılıklar olup olmadığını belirlemek için "t-testi" kullanılmıştır.

İki öbeğin sertifikasyon ifadelerine verdiği cevapların incelenmesi bazı farklılıkların olduğunu ortaya koymuştur. Nitekim sertifikasız imalatç1lar; "Firmam, çevresel açıdan sertifikalı bir ürün üretme konusunda müşterilerimiz dışındaki diğer dış ortamdaki gruplardan baskı hissetmektedir", "Firmam, çevresel açıdan sertifikalı bir ürün üretme konusunda müşsterilerimizden baskı hissetmektedir" ve "Firmam, müşterilerimizin çevresel açıdan sertifikalı bir ürüne fazladan fiyat ödemesi gerektiğine inanmaktadır" ifadeleri hariç diğer tüm ifadeleri kabul etmiştir (3’ten yukarı bir puan vermiştir). Buna karşın sertifikalı imalatçılar "Firmam, çevresel açıdan sertifikalı bir ürün üretme konusunda müşterilerimiz dışındaki diğer dış ortamdaki gruplardan baskı hissetmektedir", "Firmam, sertifikalı odun ürünleri veya hammaddeleri için daha fazla ödeme yapabilir" ve "Firmam, çevresel açıdan sertifikalı bir ürün üretme konusunda müşterilerimizden baskı hissetmektedir" ifadeleri hariç diğer tüm ifadeleri kabul etmişlerdir.

"Çevresel sertifikasyon kavramının anlaşılıp anlaşılmadığını" soran ifadeye yönelik bu iki grubun cevaplarında istatistiksel fark bulunmamaktadır. $\mathrm{Bu}$ ifadenin kabul görmesi olumlu bir durumdur. Zira bu durum imalatçıların sertifikasyon akımını eleştirel şsekilde değerlendirme ve görüşlerini hassas şekilde ortaya koyma pozisyonunda olduklar1nı göstermektedir. Eğer imalatçılar sertifikasyon kavramını anlamadıklarını belirtmiş olsalardı, o takdirde diğer ifadelere yönelik cevaplarına herhangi bir değer atfetmek güç olacaktı.

"Çevresel sertifikasyon kavramını anladıklarını" kabul etme yanında, şu ifadeler için de iki öbeğin cevapları arasında istatistiksel fark bulunmamaktadır: "Firmam, çevresel açıdan sertifikalı bir ürün üretme konusunda müşterilerimiz dışındaki diğer dış ortamdaki gruplardan baskı hissetmektedir", "Firmam, sertifikalı odun ürünleri veya hammaddeleri için daha fazla ödeme yapabilir", "Firmam, çevresel açıdan sertifikalı bir ürün üretme konusunda müşterilerimizden baskı hissetmektedir", "Firmam, odun tedarikçileri tarafindan yapılan ödeme istemlerine güvenmektedir", "Firmam, maliyetlerin sertifikasyona dâhil edilmesi gerektiğine inanmaktadır", "Firmam, bir çevre politikasına sahiptir", "Firmam, müşterilerimizin çevresel açıdan sertifikalı bir ürüne fazladan fiyat ödemesi gerektiğine inanmaktadır", "Firmam, Türkiye orman- larının çevresel sertifikasyona ihtiyacı olduğuna inanmaktadır", "Firmam, çevresel açıdan sertifikalanmış odun ürünleri veya hammadde tedarikçileri aramaktadır" ve "Firmam, çevresel sertifikasyonun Türkiye ormanlarının sağlığını sürdürmesine yardımcı olabileceğine inanmaktadır".

İki öbek, geri kalan bir ifadede istatistiksel olarak farklı cevap ortaya koymuştur. Bu ifade "Firmam, geçmiş yıllarda çevresel açıdan sertifikalanmış odun ürünleri veya hammadde satın almıştır" ifadesidir. Sertifikalı imalatçılar bu ifadeyi kesinlikle kabul etmişken (ortalama cevap puanı 4,75), sertifikasız imalatçılar kabul etmiştir (ortalama cevap puan1 3,60).

Her iki öbek de "Firmam, çevresel açıdan sertifikalı bir ürün üretme konusunda müş̧terilerimizden baskı hissetmektedir" ifadesini kabul etmemiştir. Dolayısıyla öbekler sertifikalı bir ürün üretme konusunda müşterilerinden herhangi bir baskı hissetmemektedir.

"Firmam, müşsterilerimizin çevresel açıdan sertifikalı bir ürüne fazladan bir fiyat ödemesi gerektiğine inanmaktadır" ifadesini sertifikası imalatçılar kabul etmemişken (ortalama cevap puanı 2,80), sertifikalı imalatçılar kabul etmiştir (ortalama cevap puan1 4,00). Bu durumda sertifikasız imalatçılar müşterilerinin sertifikalı bir ürüne fazladan fiyat ödeyebileceğine inanmamaktadır.

"Firmam, maliyetlerin sertifikasyona dâhil edilmesi gerektiğine inanmaktadır" ifadesini sertifikalı imalatçılar kesin olarak kabul etmişken, sertifikasız imalatçılar kabul etmektedir. Her iki grubun yaptığı seçimleri gösteren bu cevapları açıklamak mümkündür. Sertifikalı olmayı seçen sertifikalı imalatçılar, sertifikasyon sürecine dâhil olan maliyetleri iyi şekilde bilmektedir. Buna karşın sertifikasız imalatçıların sertifikasyondaki maliyet bilgileri bir dereceye kadar belirsizdir. Sertifikasız imalatçılar sertifikasyon kavramını anladıklarını kabul etmişlerdir. Böylece bu sürecin temel bilgilerine sahip oldukları varsayılabilir. Ancak sürece dâhil olan maliyetler konusunda ayrıntıları bilmeleri beklenmemelidir.

$\mathrm{Bu}$ iki öbek aynı zamanda sertifikasyona yönelik ihtiyaçlar yönündeki görüşleri konusunda da farklılaşmıştır. Nitekim sertifikalı ve sertifikasız imalatçılar "Firmam, Türkiye ormanlarının çevresel sertifikasyona ihtiyacı olduğuna inanmaktadır" ifadesini kesinlikle kabul etmişlerdir. Bu ifade her iki imalatçı öbeğin sertifikalı ürünlere yönelik müşteri talebi olmadığını kabul ettiklerinde, sertifikalı imalatçıların niçin sertifikalı bir ürün üretmeyi seçtiklerini açıklamada yardımcı 
olabilir. Eğer sertifikalı olma yönünde dış baskı yoksa, o takdirde sertifikasyona başlama kararı firma içindeki üst yönetimden kaynaklanmalıdır. Eğer yönetim sertifikasyonun bir ihtiyaç olduğunu ve çevre için iyi bir şey olduğunu düşünüyorsa, o takdirde firma için sertifikasyona başlama ve sertifikalı olma yönünde bir sebep ortaya çıkmaktadır. Sertifikalı ürünlere yönelik sınırlı bir dışsal talep ortamında dahi sertifikasyona başlayan sertifika11 imalatçılar için sebep, sertifikasyonu faydalı bir program olarak düşünmeleridir.

\subsection{7. İmalatçıların sertifikasyondan hangi faydaların elde edilebileceğine yönelik görüşleri}

Sertifikalı ve sertifikasız imalatçılardan, sertifikasyondan hangi faydaların elde edilebileceğine yönelik birkaç görüşü kabul edip etmeme yönünde puanlamaları istenmiştir. Her bir öbekte istatistiksel yönden önemli bir görüş farklılığının olup olmadığını belirlemek için "Tek yönlü varyans analizi" uygulanmış olup iki öbek için cevaplar arasında istatistiksel yönden önemli farklılıklar bulunmamıştır. Öte yandan iki öbek arasında her bir görüşe yönelik cevaplarda herhangi bir farklılığın olup olmadığını belirlemede "t-testi" uygulanmıştır.

İki öbek, bir ifadede istatistiksel olarak farklı cevap vermiştir. Bu ifade "Müşterilere fazladan fiyat ödettirilir" ifadesidir. Nitekim sertifikalı imalatç1lar bu ifadeyi kabul etmemişken (ortalama cevap puanı 2,50), sertifikasız imalatçılar kabul etmiştir (ortalama cevap puanı 3,50).

Sertifikasız imalatçıların, sertifikasyonun faydalarına yönelik "Müşteri isteklerine daha iyi cevap verilir ve ihtiyaçları karşılanır" (ortalama cevap puan 13,10), "Kârlılı̆̆l (kâr marjlarını) arttırır" (ortalama cevap puanı 3,20) ve "Piyasalardaki pay ve konum korunur" (ortalama cevap puanı 3,30) hariç diğer tüm ifadelere ortalama 3,50'den fazla puan vererek kabul ettiği anlaşılmaktadır. Sertifikalı imalatçılar ise "Kârlılı̆̆ (kâr marjlarını) arttırır" (ortalama cevap puanı 2,50), "Müşterilere fazladan fiyat ödettirilir" (ortalama cevap puanı 2,50), "Ürün fiyatlarını arttırır" (ortalama cevap puanı 3,00), "Uzun dönemli yatırım getirileri sağlar" (ortalama cevap puanı 3,00) ve "Piyasalardaki pay ve konum korunur" (ortalama cevap puanı 3,25) hariç sertifikasyonun faydalarına yönelik diğer ifadeleri kabul etmiştir.

Sertifikalı imalatçılar sertifikasyonun faydalarına yönelik ifadelerden "Yeni piyasalara ve ülkelere girişi kolaylaştırır" (ortalama cevap puanı 4,50), "Firma imajını ve itibarını iyileştirir" (ortalama cevap puanı 4,50) ve "Orman kaynaklarının korunmasını sağlar" (ortalama cevap puanı 4,50) ifadelerini kesinlikle kabul etmişken, sertifikasız imalatç1lar "Yeni piyasalara ve ülkelere girişi kolaylaştırır" (ortalama cevap puanı 3,90), "Firma imajını ve itibarını iyileştirir" (ortalama cevap puan1 4,20) ve "Orman kaynaklarının korunmaslnı sağlar" (ortalama cevap puanı 4,30) ifadelerini kabul etmiştir.

\subsection{8. İmalatçıların sertifikasyona üye olma istekliliğine yönelik koşullar}

Sertifikasız imalatçılardan, orman ürünleri sertifikasyonuna üye olma istekliliklerini etkileyebilecek koşulları kabul edip etmeme yönünde puan vermeleri talep edilmiştir. Bu soruyla, firmaların hangi durumlarda orman ürünleri sertifikasyonuna üye olabilecekleri sorgulanmıştır. Bu soruya alınan cevaplara "Tek yönlü varyans analizi” uygulanmış ve istatistiksel olarak farklılık çıkmadığ 1 için "Tukey HSD testi" uygulanmamıştır.

Sertifikasız imalatçılar "Firmam, kurumsal yönetim faaliyetlerini iyileştirmesi durumunda orman ürünleri sertifikasyonuna üye olabilecektir", "Firmam, sertifikasyonu daha iyi anladiktan ve daha ayrintılı bilgi edindikten sonra orman ürünleri sertifikasyonuna üye olabilecektir", "Firmam, kanunlar tarafindan istenmesi durumunda orman ürünleri sertifikasyonuna üye olabilecektir", "Firmam, sanayi standard olmasi durumunda orman ürünleri sertifikasyonuna üye olabilecektir", "Firmam, ürünlerimin kalitesini arttırması durumunda orman ürünleri sertifikasyonuna üye olabilecektir", "Firmam, firmamın imaj ve itibarını iyileştirmesi durumunda orman ürünleri sertifikasyonuna üye olabilecektir", "Firmam, ihracatımı arttırması durumunda orman ürünleri sertifikasyonuna üye olabilecektir" ve "Firmam, süreç içerisinde herhangi bir somut finansal kazanç delili görmem durumunda orman ürünleri sertifikasyonuna üye olabilecektir" ifadeleri ortalama 4,00 puandan az puan vererek kabul etmiştir.

Buna karşın "Firmam, orman ekosisteminin sağlı̆̆ını korudŭ̆unu görmem durumunda orman ürünleri sertifikasyonuna üye olabilecektir", "Firmam, müşterilerin sertifikasyonu talep etmeleri durumunda orman ürünleri sertifikasyonuna üye olabilecektir" ve "Firmam, satışlarımı arttırması durumunda orman ürünleri sertifikasyonuna üye olabilecektir" ifadelerini ise sertifikasız imalatçılar ortalama 4,00 ve üstü puan vererek kabul etmiştir.

\subsection{9. İmalatçıların sertifikasyonun önündeki engellere/sorunlara yönelik görüsşleri}

Sertifikalı ve sertifikasız imalatçılardan, orman ürünleri sertifikasyonuna katılımı etkilediğine 
inandıkları birkaç engeli/sorunu ve ilgisizlik nedenini kabul edip etmeme durumuna göre puanlamaları istenmiştir. Her bir grup içinde cevaplar arasında istatistiksel olarak farklılığın olup olmadığını sınamak için "tek yönlü varyans analizi" kullanılmıştır. Sertifikalı imalatçılar için cevaplar arasında istatistiksel olarak önemli farklılıklar olduğu ve buna karşın sertifikasız imalatçılar için cevaplar arasında istatistiksel yönden önemli farklılık bulunmadığ 1 tespit edilmiştir. Bu doğrultuda sertifikalı imalatçılar için elde edilen cevapları gruplandırmak için cevaplar, "Tukey HSD testi" yardımıyla çözümlenmiştir. Daha sonra iki öbek arasında her bir ifadeye yönelik cevaplarda istatistiksel açıdan farklılık olup olmadığını belirlemek için "t-testi" kullanılmıştır.

İki öbeğin sertifikasyonun önündeki engellere/ sorunlara yönelik ifadelere verdiği cevaplarda farklılıklar ortaya çıkmıştır. Buna göre sertifikasız imalatçılar; "Sertifikalı ürünlere fazladan fiyat ödettirilme yoktur", "Sertifikalı ürün isteyen ülkelere ihracat kısıtlıdır" ve "Orman Genel Müdürlüğü ilgisizdir" ifadeleri hariç diğer tüm ifadelere 3,00'dan yukarı puan vererek kabul etmiştir. Buna karşın sertifikalı imalatçılar ise "Sertifikalı ürün isteyen ülkelere ihracat kısıtlıdır" ifadesi hariç diğer tüm ifadeleri kabul etmiştir.

"Yeterli sertifikall hammadde mevcut değildir (yeterli arz yoktur)", "Sertifikal olmanın maliyeti yüksektir" ve "Sertifikall ürünlere fazladan fiyat ödettirilme yoktur" ifadeleri için, iki öbeğin cevapları arasında istatistiksel fark bulunmaktadır. Bunlardan "Yeterli sertifikall hammadde mevcut değildir (yeterli arz yoktur)" ifadesini sertifika11 imalatçılar kesinlikle kabul etmişken (ortalama cevap puanı 4,75), sertifikasız imalatçılar kabul etmiştir (ortalama cevap puanı 3,50). "Sertifikalı olmanın maliyeti yüksektir" ifadesini sertifikalı imalatçılar kabul etmişken (ortalama cevap puanı 4,25), sertifikasız imalatçılar ne kabul etmiş ne de kabul etmemiştir (ortalama cevap puanı 3,40). Buna karşın "Sertifikalı ürünlere fazladan fiyat ödettirilme yoktur" ifadesini sertifikalı imalatçılar kesinlikle kabul etmişken (ortalama cevap puanı 5,00), sertifikasız imalatçılar ne kabul etmiş ne de kabul etmemiştir (ortalama cevap puanı 2,60).

Şu ifadeler için ise iki öbeğin cevapları arasında istatistiksel yönden bir fark bulunmamaktadır: "Sertifikalı ürün isteyen ülkelere ihracat kısttldır", "Sertifikalı ürünler için pazar yoktur ve müşteriler tarafindan ihtiyaç duyulmamaktadır", "Çevreci sivil toplum kuruluşları ilgisizdir", "Sektörde çalışan orman ürünleri imalatçıları için bir önkoşul değildir", "Orman Genel Müdürlüğü ilgisizdir" ve "Firmaya ekonomik getirileri (artan satışlar, kar- lar, piyasa paylaşımları ve fiyatlar) düşüktür".

\section{Tartışma ve Sonuç}

$\mathrm{Bu}$ araştırmanın iki ana amacı bulunmaktadır. Bunlar; Batı Akdeniz Bölgesindeki sertifikalı ve sertifikasız orman ürünleri imalatçılarının genel özelliklerini tanımlamak ve bu imalatçıların sertifikasyon uygulamasına yönelik görüşlerini karşılaştırmaktır. Bu amaçlara yönelik özgün verilere sertifikalı ve sertifikasız imalatçılara yönelik bir anket yoluyla ulaşılmıştır.

Sertifikasız imalatçılar, sertifikalı imalatçılardan daha küçük ölçeklidir. Sertifikasız imalatçılar tarafından istihdam edilen tam-zamanlı çalışanların medyan sayısı 66 iken sertifikalı imalatçılar tarafından istihdam edilenlerin medyan sayısı 232'dir. Aynı zamanda sertifikasız imalatçıların medyan y1llık üretimi $8.000 \mathrm{~m}^{3}$ iken sertifikalı üreticilerin medyan yıllık üretimi $235.000 \mathrm{~m}^{3}$ 'tür. İstatistiklerin tamamı, daha büyük orman ürünleri imalatçılarının sertifikalı olmasının daha muhtemel olduğunu göstermektedir.

Bu çalışmada sertifikasız imalatçıların, sertifikalı orman ürünleri imalatında kullanıma yönelik sertifikalı hammadde için sertifikasız hammaddenin piyasa fiyatı üzerinde herhangi bir fazladan fiyat ödeyebilme durumu araştırılmıştır. Buna göre çalışma katılımcılarının \%10'u sertifikalı hammadde satın alacağı zaman sınırsız bir fazladan fiyat ödemeye istekli iken \%50'si sertifikalı hammadde satın alacağ1 zaman herhangi bir fazladan fiyat ödemeye istekli olmadığı ve geriye kalan \%40’ının ise fazladan bir fiyat ödemeye istekli olduğu belirlenmiştir. Alt (2001) tarafından ABD yapraklı tür parke imalatçıları üzerinde yapılan bir araştırmada ise bu oranlar sirasiyla $\% 80, \% 0$ ve $\% 20$ olarak tespit edilmiştir.

Çalışmamızda sertifikasız imalatçılardan CoC sertifikasyonuna yönelik ödeme istekliliğini belirtmeleri istendiğinde, katılımcıların \%80'inin eğer ücretsiz olursa firmalarının $\mathrm{CoC}$ sertifikasyonuna tabi olacağını belirttiği ve geri kalan \%20'sinin ise herhangi bir maliyete maruz kalması durumunda firmalarının $\mathrm{CoC}$ sertifikasyonuna tabi olmayacağını ifade ettiği ortaya çıkmıştır. Alt (2001)'in ABD yapraklı tür parke imalatçılarına yönelik yaptığı araştırmada ise katılımcıların \%31'inin eğer ücretsiz olursa firmalarının $\mathrm{CoC}$ sertifikasyonuna tabi olacağı, \%51'inin herhangi bir maliyete maruz kalması durumunda firmalarının CoC sertifikasyonuna tabi olmayacağ 1 ve \%17'sinin ise belirli bir para miktarını geçmemesi halinde firmalarının CoC sertifikasyonuna tabi olacağı belirlenmiştir. 
Aynı zamanda bu çalışmadaki sertifikasız imalatçılardan, sertifikalı orman ürünleri üretimine başlamak için bu ürünlere yönelik müşterilerinden almaya ihtiyaç duyduğu fazladan fiyatın ne olduğu sorulmuştur. Buna göre sertifikasız imalatçıların $\% 70$ 'i, eğer fazladan fiyat yoksa sertifikalı orman ürünleri imal etmeye istekli olacağını belirtmiştir. Buna karşın imalatçıların \%30’u, herhangi bir fazladan fiyat durumunda sertifikalı orman ürünleri imal etmeye isteksiz olacağını dile getirmiştir. Alt (2001) tarafından ABD yapraklı tür parke imalatçıları için yapılan araştırmada ise sertifikasız imalatçıların \%3'ü eğer fazladan fiyat yoksa sertifikalı orman ürünleri imal etmeye istekli olacağ1n1, \%46's1 herhangi bir fazladan fiyat durumunda sertifikalı orman ürünleri imal etmeye isteksiz olacağını ve kalan \%51'i ise eğer sertifikalı orman ürünleri için belirli bir fazladan fiyat getiriyorsa sertifikalı orman ürünleri üretmeye istekli olacağ 1 ortaya çıkmıştır.

Araştırmanın bir diğer amacı, imalatçıların sertifikasyon konusundaki görüşlerini ortaya koymaktır. İlk olarak imalatçılardan, olası sertifikasyon düzenleyici ve denetleyicisi kuruluşlara yönelik tercihlerini puanlamaları istenmiştir. Hem sertifikalı hem sertifikasız imalatçılar, listenin üstüne bağımsız ve tarafsız seçenekleri (özel bir üçüncü taraf sertifikasyon firması, orman ürünleri sanayi birlikleri veya meslek odaları ve orman ürünleri firmalarının bizzat kendileri) yerleştirmişken, listenin altında ise bir devlet kuruluşu ve bir STK çevre örgütünü koymuşlardır.

Sertifikalı ve sertifikasız imalatçılara göre eğer bir örgüt sanayiyi düzenleyecekse bu örgütün tarafsız ve dürüst olması gerekmektedir. Öte yandan hem sertifikalı hem de sertifikasız imalatçıların özel bir üçüncü taraf sertifikasyon programlarını çok güvenilir olarak puanlamaları ilgi çekicidir. $\mathrm{Bu}$ durum üçüncü taraf sertifikasyon programlarının sertifikasyon akımının bağımsız düzenleyicileri olarak görüldüğü ve sertifikasyonu denetlemek için sanayi içinde imalatçılar tarafından güven duyulduğu anlamına gelmektedir.

Sertifikasyon taahhüdünde (çevresel idareye) bulunma ihtiyacında olan sertifikasız imalatçılara, taahhüt ihtiyacının olası nedenleri sunulmuş ve her bir nedeni kabul edip etmeme düzeylerini oylamaları istenmiştir. "Üst yönetimin sorumluluk hissetmesi" dişında diğer yüksek oranda puanlanan nedenlere "Firma imajin koruma arzusu" ve "Devlet yasası" dâhildir. Bu cevaplar göstermektedir ki, bir firma üzerine bir çevre politikası geliştirme yönünde dış baskı sınırlıysa, o takdirde bir çevre politikasını benimsek için yönetimin kendinden kaynaklı bir neden olmalıdır. Firma yönetiminin çevresel politika geliştirmenin bir ihtiyaç olduğunu ve firmanın bu politikadan bir fayda elde edeceğini düşünmesi gereklidir. Diğer bir ifadeyle yönetim, sınırlı bir dış baskıda firmalarının bir fayda elde edeceğini düşünüyorsa bir çevre politikasını yürütmeyi tercih edecektir.

$\mathrm{Bu}$ çalışmada sertifikasız imalatçılar "Firmam sertifikasyon kavramını anlamaktadır" ifadesine 5 puan üzerinden 3,50 puan vererek kabul etmiştir. Ölçülen sertifikasyon farkındalığındaki bu puan, sertifikasız firmaların sertifikasyon akımının geliştirilmesine dikkat ettiklerini göstermektedir. Sertifikasyon ve çevresel konular kitle iletişim araçlarında daha fazla yer aldıkça ve toplumda bu konulara güçlü bir ilgi oluştukça, sertifikasyon farkındalığındaki artışın sertifikasız imalatçılar arasında devam edeceği beklenebilir.

Bu çalışmada sertifikasız imalatçılar, her ne kadar sertifikasyon kavramını anladıklarını ifade etseler de müşterilerinin çevresel açıdan sertifikalı bir ürüne fazladan fiyat ödemesi gerektiğine inanmamaktadır. Aynı zamanda sertifikasız imalatçılar "Çevresel açıdan sertifikalı bir ürün üretme konusunda müşterilerinden baskı hissetmektedir" ve "Çevresel açıdan sertifikalı bir ürün üretme konusunda müş̧terilerimiz dışındaki diğer dış ortamdaki gruplardan baskı hissetmektedir" ifadelerini kabul etmemiştir.

"Firmam çevre politikasına sahiptir", "Firmam çevresel sertifikasyonun Türkiye ormanlarının sağlığını sürdürmesine yardımcı olabileceğine inanmaktadır" ve "Firmam Türkiye ormanlarının çevresel sertifikasyona ihtiyacı olduğuna inanmaktadır" ifadelerinde, sertifikalı imalatçılar ile sertifikasız imalatçılar uyum içerisindedir.

Eğer bir firma sertifikalı olma konusunda içsel veya dışsal bir baskı düşünüyorsa harekete geçecektir. Her iki imalatçı grubu da sertifikalı olmak için dışsal baskı olmadığını kabul etmektedir. Sertifikalı imalatçılar içsel baskıyı düşündüklerinden dolayı, her ne kadar dışsal baskı olmasa da sertifikasyona başlama ve sertifikalı olma kararını vermiştir.

Araştırmada uygulanan "Tek yönlü varyans analizi" sonuçları, sertifikasız imalatçılar için düzenleyici ve denetleyici makamlara yönelik güven sıralamasının istatistiksel olarak önemli farklılığa sahip olduğunu ortaya koymuş, yani $\mathrm{H}_{1}$ sertifikaS1z imalatçılar için kabul edilmiştir. Buna karşın bu sıralama sertifikalı imalatçılar için istatistiksel açıdan önemli farklılık içermediğinden, sertifikalı imalatçılar için $\mathrm{H}_{1}$ reddedilmiştir.

Ardından gerçekleştirilen “t-testi” karşılaştırmala- 
rı, sertifikasız ve sertifikalı imalatçıların bir devlet kuruluşu ve bir STK çevre örgütüne istatistiksel olarak önemli farklı sıralama verdiğini, buna karşın diğer kuruluşlara istatistiksel açıdan önemli bir farklılığg olmayan bir sıralamayı uygun gördüğünü ortaya koymuştur. Böylece iki öbeğin bir devlet kuruluşu ve bir STK çevre örgütüne yönelik güven sıralaması görüşleri için $\mathrm{H}_{2}$ kabul edilmişken diğer kuruluşlara yönelik güven sıralaması görüşleri için $\mathrm{H}_{2}$ reddedilmiştir.

Sertifikasız ve sertifikalı imalatçıların sertifikasyon uygulamasına yönelik görüşlerinde istatistiksel açıdan önemli farklılıklar olduğu ortaya çıktığından $\mathrm{H}_{3}$ kabul edilmiştir.

Sertifikasız ve sertifikalı imalatçıların sertifikasyona yönelik görüşleri arasında istatistiksel yönden bazı farklılıklar olduğu belirlendiğinden $\mathrm{H}_{4}$ kabul edilmiştir.

Sertifikasız ve sertifikalı imalatçıların sertifikasyondan hangi faydaların elde edilebileceğine yönelik görüşlerinde istatistiksel olarak önemli bir farklılık olmadığ 1 ortaya çıkmıştır. Bu nedenle $\mathrm{H}_{5}$ reddedilmiştir.

Sertifikasız ve sertifikalı imalatçılar sadece "Müşterilere fazladan fiyat ödettirilir" ifadesi için istatistiksel açıdan farklı cevap vermiş olup sadece bu ifade için $\mathrm{H}_{6}$ kabul edilmiştir.

Sertifikasız ve sertifikalı imalatçıların orman ürünleri sertifikasyonuna katılımı etkilediğine inandıkları engeller/sorunlar ve ilgisizlik nedenleri arasında istatistiksel olarak farklılık olup olmadığ sınandığında, sertifikalı imalatçılar için istatistiksel açıdan önemli farklılıklar olduğu, buna karşın sertifikasız imalatçılar için istatistiksel olarak önemli farklılık bulunmadığı belirlenmiştir. $\mathrm{Bu}$ nedenle $\mathrm{H}_{7}$ sertifikalı imalatçılar için kabul ve sertifikasız imalatçılar için reddedilmiştir.

İki öbeğin sertifikasyonun önündeki engeller/ sorunlara yönelik görüşlerde istatistiksel yönden önemli farklılık ortaya çıktığından $\mathrm{H}_{8}$ kabul edilmiştir.

Sertifikasız imalatçıların orman ürünleri sertifikasyonuna üye olma istekliliğine yönelik koşulları arasında istatistiksel olarak önemli bir farklılık çıkmamıştır. Böylece $\mathrm{H}_{9}$ reddedilmiştir.

Sertifikasyona ihtiyaç duyan sertifikasız imalatç1ların her birisinin ihtiyaç nedenleri arasında istatistiksel açıdan önemli farklılık belirlendiğinden ise $\mathrm{H}_{10}$ kabul edilmiştir.

Her ne kadar halen sertifikalı hammadde bulmakta güçlük yaşanıyor olsa bile, gelecek yıllarda daha büyük açık da yaşanabilecektir. Bu nedenle Orman Genel Müdürlüğü, sertifikalı hammaddeye yönelik talep artışına bugünden kendisini hazırlamalıdır.

Bu çalışma, Batı Akdeniz Bölgesi orman ürünleri sanayinde orman sertifikasyonuna yönelik farkındalık ve anlayışında genel bir eksiklik olduğunu göstermektedir. Daha büyük bir kabulü elde etmek için bölgedeki hem imalatçılar hem de müşteriler için sertifikasyona yönelik farkındalık ve bilgiye yönelik daha büyük çaba gösterilmelidir. Bir başka ifadeyle sertifikalı orman ürünlerinin mevcudiyetine yönelik daha geniş farkındalığa ihtiyaç bulunmaktadır. Genel sertifikasyon kavramı kapsamındaki konular hakkında toplumu eğitmek için sanayi ve topluma yönelik eğitim/farkındalık programlarına ihtiyaç bulunmaktadır. Bunun için sertifikalı orman ürünlerinin faydaları ile ilgili sanayi ve toplumu bilgilendirme yönünde eğitim faaliyetlerine ihtiyaç vardır. Bu kapsamda farklı kitle iletişim araçları kullanılarak orman sertifikasyonu konusunda yaygın eğitimler düzenlenmelidir. Aynı zamanda çevresel sertifikasyon konusundaki ilgi gruplarını eğitmek için toplantılar da organize edilmelidir.

Sertifikalı orman ürünlerine yönelik yurt dışı (Avrupa ülkeleri, ABD, Kanada, Japonya vb.) ile yurt içi pazarlar, hangi tip sertifikalı orman ürünleri talepleri olduğu ve sertifikalı yerli orman ürünleri sanayi işletmelerinin bu pazarlara daha büyük oranda girişinin nasıl olacağını belirleyecek tamamlayıcı pazar araştırmaları yapılmalıdır.

\section{Teşekkür}

$\mathrm{Bu}$ makale, Orman Genel Müdürlüğü, Batı Akdeniz Ormancılık Araştırma Enstitüsü Müdürlüğünce "Sertifikasyonun Batı Akdeniz Orman Ürünleri Sanayisi Üzerindeki Etkileri" ismiyle ve 19.5310/2018-2020 proje numarasıyla gerçekleştirilen araştırma sonucunda hazırlanan ve OGM Araştırma İhtisas Grupları Toplantısında yayınlanmas1 yönünde karar verilen Proje Sonuç Raporunun (Y1lmaz ve ark., 2020b) bir bölümünün özetidir. Bulgular bölümünde yapılan açıklamalara ait tüm özgün çizelgelere Proje Sonuç Raporundan ulaş1labilecektir. Araştırmaya, Batı Akdeniz Bölgesindeki orta ve büyük ölçekli orman ürünleri sanayi temsilcileri, Batı Akdeniz Ormancılık Araştırma Enstitüsü Müdürlüğü, Antalya Orman Bölge Müdürlügü ve orman ürünleri sanayindeki uzmanlar dâhil olmuşlardır. Verdikleri destek için kendilerine teşekkür ederiz. 


\section{Kaynaklar}

Aguilar, F. X., Vlosky, R. P., 2007. Consumer willingness to pay price premiums for environmentally certified wood products in the U. S. Forest Policy and Economics, 9 (8): 1100-1112.

Akyol, A., Yıldız, M., 2018. Sertifikalı orman ürünlerine yönelik tüketici tercih ve algıları. Ziraat, Orman ve Su Ürünleri Alanında Yenilikçi Yaklaşımlar, ISBN:978605-288-793-6, s:43-58, Gece Kitaplığı, Ankara.

Alt, C., 2001. The impact of environmental certification on U.S. hardwood flooring manufacturers. Forest Products Marketing and Management, Virginia Polytechnic Institute and State University, 172 pages, USA.

Anderson, R. C., Hansen, E. N., 2004. Determining consumer preferences for ecolabeled forest products. Journal of Forestry, 102 (4): 28-32.

Bigsby, H., Ozanne, L. K., 2002. The purchase decision: consumers and environmentally certified wood products. Forest Products Journal, 52 (7/8): 100-105.

Bond, B., Lyon, S., Munsell, J., Barrett, S., Gagnon, J., 2014. Perceptions of Virginia's primary forest products manufacturers regarding forest certification. Forest Products Journal, 64 (7/8): 242-249.

Chen, J., Innes, J. L., Tikina, A., 2010. Private cost-benefits of voluntary forest product certification. International Forestry Review, 12 (1): 1-12.

Dursun, Ö., Daşdemir, İ., 2016. The impacts of FSC certification process on Keles Forest Enterprise. International Forestry Symposium (IFS 2016), Proceedings Book, pp.317-329, 07-10 December, Kastamonu University, Faculty of Forestry, Kastamonu-Turkey.

Dursun, Ö., Daşdemir, İ., 2017. İnegöl Orman İşletmesinde FSC sertifikasyon sürecinin etkileri. Türkiye Ormancılar Derneği IV. Ulusal Ormancılık Kongresi, Bildiriler Kitabı, 15-16 Kasım, Antalya.

Ebeling, J., Yasue, M., 2009. The effectiveness of market-based conservation in the tropics: forest certification in Ecuador and Bolivia. Journal of Environmental Management, 90: 1145-1153.

Forsyth, K., Haley, D., Kozak, R., 1999. Will costumers pay more for certified wood products? Journal of Forestry, 97 (2): 18-22.

Genç, A., 2014. Orman yönetim sertifikası uygulamalarında karşılaşılan sorunlar ve çözüm önerileri (Kastamonu Orman Bölge Müdürlüğü örneği). Kastamonu Üniversitesi, Fen Bilimleri Enstitüsü, Orman Mühendisliği Anabilim Dalı, Yayınlanmamış Yüksek Lisans Tezi, 122 sayfa, Kastamonu.

Geray, U., 1999. Türkiye'de orman sertifikalandırma olabilirlik raporu. İ.Ü. Orman Fakültesi, Ormancılık Ekonomisi Anabilim Dalı, Haziran, 32 sayfa, İstanbul.

Hansen, E., 1997. Forest certification and its role in mar- keting strategy. Forest Products Journal, 47 (3): 16-22.

Hubbard, S. S., Bowe, S. A., 2005. Environmentally certified wood products: perspectives and experiences of primary wood manufactures in Wisconsin. Forest Products Journal, 55 (1): 33-40.

Jayasinghe, P., Allen, D. S., Bull, G. Q., Kozak, R. A., 2007. The status of forest certification in the Canadian value-added wood products manufacturing sector. The Forestry Chronicle, 83 (1): 113-125.

Jensen, K., Jakus, P. M., English, B., Menard, J., 2003. Market participation and willingness to pay for environmentally certified products. Forest Science, 49 (4): 632-641.

Karagöz, F., 2010. Orman koruma ve gözetim zinciri. Eko Yapı Dergisi, 4: 104-108.

Karagöz, Ü., Kaymakçı, A., Bayram, B. Ç., Akyıldız, M. H., Ateş, S., Karagöz, F., 2011. Odun ve odun ürünlerinin sertifikasyonu. I. Ulusal Akdeniz Orman ve Çevre Sempozyumu, 26-28 Ekim 2011, Tebliğler Kitabı, Sayfa: 709-719, Kahramanmaraş.

Koç, M., 2016. Orman ürünleri pazarlarında sertifikalı ürünlerin analizi. İstanbul Üniversitesi, Fen Bilimleri Enstitüsü, Orman Mühendisliği Anabilim Dalı, Yayınlanmamış Yüksek Lisans Tezi, 107 sayfa, İstanbul.

Koçak, S., 2016. Türkiye'de orman sertifikasyonu uygulamalarının orman kaynaklarının yönetimine getirdiği etkiler. Süleyman Demirel Üniversitesi, Fen Bilimleri Enstitüsü, Yayınlanmamış Yüksek Lisans Tezi, 76 sayfa, Isparta.

Koçak, S., Tolunay, A., Türkoğlu, T., 2017. Türkiye'de orman sertifikasyonu uygulamalarının orman kaynakları yönetimine etkileri. Türkiye Ormancılık Dergisi, 18 (1): 49-56, Isparta.

Komut, O., 2016. Türkiye'de ormancıllk ve orman ürünleri endüstrisinde sertifikasyon: Sektörel durum ve farkındalık çözümlemesi. Artvin Çoruh üniversitesi, Fen Bilimleri Enstitüsü, Orman Mühendisliği Anabilim Dalı, Yayınlanmamış Doktora Tezi, 214 sayfa, Artvin.

Kozak, R. A., Cohen, D. H., Lerner, J., Bull, G. Q., 2004. Western Canadian consumer attitudes towards certified value-added wood products: An exploratory assessment. Forest Products Journal, 54 (9): 21-24.

Mohamed, S., Ibrahim, M. L., 2007. Preliminary study on willingness to pay for environmentally certified wood products among consumers in Malaysia. Journal of Applied Sciences, 7 (9): 1339-1342.

Owari, T., Juslin, H., Rummukainen, A., Yoshimura, T., 2006. Strategies, functions and benefits of forest certification in wood products marketing: perspectives of Finnish suppliers. Forest Policy and Economics, 9: 380391.

Ozanne, L. K., Vlosky, R. P., 1997. Willingness to pay for environmentally certified wood products: A consum- 
er perspective. Forest Products Journal, 47 (6): 39-48.

Ozanne, L. K., Vlosky, R. P., 2003. Certification from the US consumer perspective: A comparison from 1995 and 2000. Forest Products Journal, 53 (3): 13-21.

Özdamar, K., 2009. Paket Programlar ile İstatistiksel Veri Analizi 1. Yenilenmiş 7. Baskı, Kaan Kitabevi, 609 sayfa, Eskişehir.

Rametsteiner, E., Simula, M., 2003. Forest certification - An instrument to promote sustainable forest management? Journal of Environmental Management, 67 (1): 87-98.

Ratnasingam, J., Macpherson, T. H., Joras, F., 2008. An assessment of Malaysian wooden furniture manufacturers' readiness to embrace Chain of Custody $(\mathrm{CoC})$ certification. European Journal of Wood and Wood Products, 66: 339-343.

Stevens, J., Ahmad, M., Ruddell, S., 1998. Forest products certification: A survey of manufacturers. Forest Products Journal, 48 (6): 43-49.

Şener F.N., 2009. Türkiye‘de sürdürülebilir ormancılık uygulamalarının sertifikasyon ve akreditasyonunda sivil ve idari yapılanma [Andırın Devlet Orman İşletme Müdürlüğü ve Göksun Devlet Orman İşletme Müdürlüğü Örneği (2003-2007)]. KSÜ, Fen Bilimleri Enstitüsü, Yayınlanmamış Yüksek Lisans tezi, 114 sayfa, Kahramanmaraş.

Şener, F. N., 2016. Sürdürülebilir orman yönetimi süreçlerinde Türkiye'nin konum analizi. Süleyman Demirel üniversitesi, Fen Bilimleri Enstitüsü, Yayınlanmamış Doktora Tezi, 326 sayfa, Isparta.

Şener, F. N., Tolunay, A., Görücü, Ö., 2011. Sürdürülebilir ormancılık uygulamalarında sertifikasyon ve akreditasyon: Andırın ve Göksun Devlet Orman İşletme Müdürlükleri örneği. SDÜ Orman Fakültesi Dergisi, 12: 115-125.

Şensöz, İ. H., 2014. Ormanc1lıkta sertifikasyon ve ormancılık politikası açısından önemi. İ.Ü. Fen Bilimleri Enstitüsü, Yayınlanmamış Yüksek Lisans Tezi, 98 sayfa, İstanbul.
Tikina, A. V., Innes, J. L., 2008. A framework for assessing the effectiveness of forest certification. Canadian Journal of Forest Research, 38 (6): 1357-1365.

Türkoğlu, T., 2009. Türkiye'de ormanların ve orman ürünlerinin sertifikalandırılması. II. Ormancılıkta Sosyo-Ekonomik Sorunlar Kongresi, 19-21 Şubat 2009, SDÜ, Tebliğler Kitab1, Sayfa: 378-388, Isparta.

Türkoğlu, T., 2011. Türkiye'deki orman endüstrisi işletmelerine sürdürülebilir orman yönetimi çerçevesinde odun hammaddesi tedariki ve orman ürünlerinin sertifikasyonu. Süleyman Demirel Üniversitesi, Fen Bilimleri Enstitüsü, Yayınlanmamış Doktora Tezi, 243 sayfa, Isparta.

Türkoğlu, T., Tolunay, A., 2013. Türkiye'deki orman ürünleri ithalatçısı işletmelerin sertifikalı orman ürünlerine ilişkin görüşleri. SDÜ Orman Fakültesi Dergisi, 14: $95-101$.

Türkoğlu, T., Tolunay, A., 2014. FSC Orman yönetim sertifikasının Muğla ormanlarına etkisinin nitel olarak araştırılması. II. Ulusal Akdeniz Orman ve Çevre Sempozyumu, "Akdeniz ormanlarının geleceği: Sürdürülebilir toplum ve çevre", 22-24 Ekim 2014, Tebliğler Kitab1, Sayfa: 506-517, Isparta.

Vidal, N., Kozak, R., Cohen, D., 2005. Chain of Custody certification: An assessment of the North American solid wood sector. Forest Policy and Economics, 7 (3): 345-355.

Vlosky, R. P., Ozanne, L. K., 1998. Environmental certification of wood products: The U. S. manufacturers' perspective. Forest Products Journal, 48 (9): 21-26.

Yılmaz, E., Alkan, S., Kayacan, A., Bayir, Y., Mavi, Z., 2020a: Bat1 Akdeniz Bölgesindeki Orman Ürünleri Sanayinin Sertifikasyona Yönelik Kararı ve Bu Kararın Etkileri. Ormancılık Araştırma Dergisi, 7 (2), 147-161

Y1lmaz, E., Alkan, S., Kayacan, A., Bayir, Y., Mavi, Z., 2020b: Sertifikasyonun Bat1 Akdeniz orman ürünleri sanayisi üzerindeki etkileri. T.C. Tarım ve Orman Bakanlığı, Batı Akdeniz Ormancılık Araştırma Enstitüsü Müdürlüğü, Sonuçlanan Proje Sonuç Raporu, 100 sayfa, Antalya. 